\title{
2
}

\section{The challenge for Australian foreign-policy professionals}

\author{
David W. Lovell
}

Most of the chapters in this collection are by specialists in the Asia-Pacific region, each of them expert in the politics of its various countries and their numerous interactions. It is a region so vast - extending, on some accounts, from the shores of the Americas to the Indian subcontinent, and from Dunedin to Vladivostok and Anchorage, and embracing dozens of countries..-that a significant amount of specialization is only to be expected. Without a detailed knowledge of the history of particular countries, of their relationships with others, their institutions, policy makers, and aspirations, making foreign policy would be even more hazardous than it currently is.

My contribution is not expert in the same way, but I think it is nevertheless appropriate in any serious discussion of policy making and implementation. I will not canvass particular regional issues here. Instead, I want to draw attention to another type of challenge that confronts foreign-policy professionals. As well as developing and maintaining their specialized knowledge, they must remain acutely aware that specialization itself can produce problems if it is not leavened by broader perspectives, and by an approach to detailed information that is selfconsciously cautious and critical. Australian foreign-policy professionals - those people who advise politicians in this area, who implement policy, and who comment upon it in the media--are professional only in so far as they combine detail with perspective, contemporary comment with a sense of history, and advice with a sense of their own responsibilities in the larger task of managing foreign relations. Developments in the Asia-Pacific region are now calling, perhaps more urgently than ever before, for the deployment of those skills. In this chapter, therefore, I shall reflect on some issues of perspective. I shall caution, in particular, against unexamined assumptions on a couple of fundamental issues on the grounds that they might distort policy making, and diminish Australia's ability to benefit from the current situation. 
Though it is difficult to be categorical about such things, we seem to be at a time of historic change in international relations. As with earlier times of transition in relations between states, there is a perceptible and rapid change in the balance of forces in the world. Emerging powers are beginning to find their places at the table of the established powers, and to explore new ways of doing business with each other. It is a change that was precipitated by the end of the Cold War, and the predominantly bi-polar world that characterized it; and it is pushed along by the economic rise of countries such as India and China. In my view, this transition period presents a historic opportunity for Australia.

The jostling for position at the table of power contains considerable challenges for policy makers of the major powers themselves, especially those in the United States and China. For the focus of international attention has begun to move from Europe to the Asia-Pacific region. The region is increasingly significant for Australia, not as a source of threat and insecurity as it once chiefly was, but as a place in which to play a positive role and, in important respects, to find a rightful "home'. It does not promise to be an easy path, but it is a necessary one if we are serious about a secure future. The role of foreign-policy professionals will be a crucial one both in getting the best for Australia out of the current transition, and in getting the best outcome for the region. The domestic profile of Australia's foreign-policy professionals may be low, but their job is crucial to good policy, its successful implementation, and its public acceptance. If they can combine specialized knowledge with sound judgement, they will contribute to the emergence of a more stable and peaceful world.

\section{Australia and the Asia-Pacific}

If Australia faces a historic opportunity in the Asia-Pacific region, it must be said that we carry with us considerable baggage, and that our outreach is a recent affair, Australia's responses to the Asia-Pacific region were, until as late as the $1950 \mathrm{~s}$ and 1960 s, characterized by an attitude that we were set apart-by our cultural origins, our political institutions, and our interests and aspirations-and, worse, that we were surrounded by a sea of dangers. Our sense of separateness led to restrictive immigration; the White Australia Policy was one of the very first acts of the new federal parliament in 1901, and was reversed only in the mid-1960s. Our sense of threat, reinforced by the Second World War, was assuaged only by looking to 'great and powerful friends'-first to the United Kingdom; then to the USA. Australia engaged with the region militarily, and in alliance with such friends, in the Korean War, the Malayan Emergency, and the Vietnam War. But with the Colombo Plan, and with a rapid increase in trade (especialiy as Japan became our major trading partner in the 1960 s), our more positive sense of taking a place in the region began. Yet, though Australia's engagement with the region is relatively recent, we should not forget that the region's sense of itself is also relatively new, as we can attest at one level by its tentative security architecture. 
The importance of the Asia-Pacific to Australia lies not just in our economic relations and trade with the region. We have increasingly recognized that our security lies with Asia-Pacific security. And, furthermore, many Australians have begun to look to the Asia-Pacific as a way of enriching our identity. There is much confusion in Australia and the region on the latter issue, and mixed messages about where Australia belongs. There are clearly tensions between Australia's geographic location at the edge of the Asia-Pacific, its roots as a European outpost, and its aspirations for acceptance within the region. Complex issues, especially around matters such as identity, are not quickly resolved. But even as Australia faces divisive political debate over such matters, and even if the final resolution may not be achieved until the next generation, the direction of movement towards engagement with the Asia-Pacific region is clear and irreversible. As we feel more comfortable about our links with the region, the region too will feel increasingly comfortable about us.

What Australia may once have considered a vulnerability-the fact, to put it bluntly, that it cannot defend itself alone-has begun to be turned into a strength. Our small population and vast coastline have meant that we have not tried to build a fortress, but that we have committed ourselves to regional engagement. Fortresses, as foreign-policy professionals would know, are temporary at best and counterproductive at worst. Australian governments of all persuasions over the past few decades have recognized that the best guarantee for our own security is the security of the region. That means, in large part, contributing to the security architecture and participating in regional dialogue. We may find that things are slow-going, that cultural differences in the approach to problems are frustrating, and that 'Australia' is used as a convenient diversion in some domestic politics of the region. But, as Winston Churchill so aptly put it, 'jaw-jaw is better than warwar'.

Australian engagement with the Asia-Pacific region has become an opportunity to play a significant role in what, in terms of global considerations, has become a key area. It is the world's most populous region. Its rising economies are the source of considerable hope for world economic health, and its downturns-m-such as in 1998-have had major repercussions. Above all, we are witnessing the emergence of China as an economic powerhouse, and the beginning of its integration into the world economy. China is now Australia's third-largest trading partner. The importance of the region was signaled by the remarks of newlyelected US President George W. Bush in late 2000, that the US would turn its strategic focus towards Asia. Though the threat of terrorism has since shifted the general perception of strategic priorities, the underlying claims of the Asia-Pacific region to our attention remain compelling. But such claims arise not just because of Asia's economic potential; they also arise because there are a number of interstate tensions here that could lead to major conflict, and a number of internal difficulties in many of the states, including ethnic conflict, separatist struggles, and 
the destabilizing effects of pervasive corruption. Many of these conflicts have the potential to draw the region into violence.

Australian foreign policy, therefore, faces a critical moment. It must find a way ahead for Australia in a region which is of national and global significance. It must reassess its existing commitments, and be open to new options. In all of this it can enhance not just its own security, but the security of the region. One of the key elements in taking advantage of these opportunities is to have foreign-policy professionals who are aware of the challenges and their own responsibilities.

\section{The responsibilities of foreign-policy professionals}

Most Australian foreign-policy professionals work within an established set of rules and norms about responsible government, and about the consequent role of career public servants as anonymous advisers, and implementers of the will of the government of the day. In recent decades, the distinctions between permanent public servants and transient politicians, and between public servants as implementers but not makers of policy, have become blurred. Furthermore, some policy-makers do not fit neatly within the established framework: ministerial advisers, for example, who are brought into an office because of a particular expertise; or scholars, who may be co-opted onto advisory councils. Yet whatever their status, these professionals share two common features. They are, in the first place, expert; and they are, in the second place, removed from direct pressures of publicly-contested office. In both respects, they are unlike politicians. Politicians, or at least the best of them, are generalists, able quickly to comprehend a brief. And they are in direct touch with popular feeling (which is not to say that they should pander to it).

Although it is a rather different policy-making and bureaucratic environment from that in Australia, Henry Kissinger's reflections on US President Ronald Reagan bring into focus the different strengths of politicians and policy professionals. As Kissinger relates $(1994,765)$, 'The details of foreign policy bored Reagan. He had absorbed a few basic ideas about the dangers of appeasement, the evils of communism, and the greatness of his own country, but analysis of substantive issues was not his forte.' And yet, he continues, Reagan went on 'to develop a foreign policy of extraordinary consistency and relevance'.

Few foreign-policy professionals have the profile of a Kissinger, but their generally low profile should not disguise their importance, especially as few politicians can nowadays resist the temptation to personal meetings and summits with foreign leaders, and the associated opportunities for publicity, while professional negotiators and diplomats are sidelined. As the fifteenth-century statesman and historian Philippe de Commynes advised in his Memoirs, 'great princes who wish to establish good personal relations should never meet each other face to face, but ought to communicate through good and wise ambassadors' (Hamilton and Langhorne 1995, 223). But with politicians on the loose, 
brandishing airline tickets, the role of the policy professional becomes even more important. The grounds for meetings must be thoroughly prepared, and the politicians must be as well informed as possible.

It is the strength, and the frustration, of democratic politicians that they listen to many voices, from many quarters. But -... whatever they do with it - they have a right to expect the best advice from their foreign-policy professionals, and from public servants more generally. Foreign-policy professionals, therefore, have particular responsibilities in the way they fulfil their role. They must work hard to maintain their specialized knowledge; they must develop a sense of perspective and judgement; and they must keep questioning their assumptions.

In the first place, foreign-policy professionals have a responsibility to know their area, to remain up-to-date on the key issues of concern, to be aware of cultural, political, and historical backgrounds and sensitivities. That includes being aware of the connections between domestic and foreign policies of their countries of specialization. Just as the foreign policy of our own state is affected by numerous factors, including the priorities of the incumbent government and bureaucratic politics, the foreign policies of other states are similarly complex. Indeed, the preoccupations of many, if not all, the countries of the Asia-Pacific region are in domestic matters: problems (in no particular order) of economic growth, modernization, pollution, governance, health and education. China's socialist market economy, for example, is an unprecedented experiment, the details and workings of which will need to be closely watched.

Foreign-policy professionals have a particular skill at decoding messages, for foreign relations have their own peculiar sensitivities. Diplomacy attends to words and gestures and moods far more carefully than ordinary exchanges. For this is an area in which a misjudged word, or a misinterpreted message, can have disastrous consequences. It is for this reason that the 'temperature' of a relationship needs to be constantly monitored, and messages conveyed accordingly. Australia may have a particular advantage in this area. Australians-if I may resort to the unfashionable area of national stereotype - are reluctant to give offence, and rarely give offence deliberately. (I am remined of some reminiscences of my late friend, Eugene Kamenka, who observed that when he arrived in Australia in the 1930s, a German-speaking Russian Jew fleeing from Nazism, he found that the reluctance of Australians to accept such aliens was outweighed by their reluctance to be deliberately rude.) But perhaps we need to balance against this positive image the rather less welcome one of the insular Australian tourist, blundering through foreign encounters, and giving gratuitous offence.

In the second place, policy professionals must be able to see beyond the headlines, and the day-to-day static of international relations. They must have some perspective on the international scene, the larger forces as work, and the general direction of movement. They should also be aware that governments sometimes use foreign policy issues as devices to divert attention away from domestic problems. Foreign-policy professionals must therefore not be easily 
swayed by rhetoric, hyperbole or popular emotion. They must be cool-headed in the face of domestic pressures and foreign provocations.

It is also vital that foreign-policy professionals have a sense of history. It is not surprising that a country born of revolution, and promoting its ideals, is seen elsewhere as a threat, and regarded with suspicion. And, indeed, the United States was seen as a threat to the established powers of Europe for decades after its revolutionary birth.

Gaining perspective on the larger forces at work in the world gives rise to some difficult issues. There is a major debate, for example, about whether human rights are universal, in the sense of arising from the aspirations of people from diverse cultures. While it waxes and wanes, the debate over whether values are universal (Kelly and Reid 1998) may ultimately be decided in the affirmative by globalization. But if values are universal, they nevertheless still confront diverse countries and traditions, in which the ordering of their priority may be substantially different. In the midst of this diversity, no country has the right to set itself up as a crusader for its value priorities. Crusading has a deep historical stain, as a hypocritical and grubby affair which generally brings particular values themselves into question. The increasing communication and engagement at all levels between countries will lead to the interpenetration of ideas, and achieve more than stridency and force have ever done. If the west appears in the guise of human rights champion, we must remember that it earlier appeared to Asia in a rather more heavy-handed way: forcing countries open, fomenting rebellions and wars, imposing Christian missionaries, compelling trade. Idealism in foreign policy, against this background, either looks naïve or a cover for the pursuit of more mundane material interests.

To develop perspective and judgement, foreign-policy professionals must be open to different and challenging ideas. One of the major temptations of specialists is to keep moving in the same circles, talking to the same people, and not broadening or challenging their own views. They must, of course, travel; they should have some specialist language training; they should be encouraged to move from one organization to another in foreign-policy making circles; and they should attend professional conferences. Closed communities, whether of specialists or not, are self-reinforcing and ultimately self-deceiving.

In the third place, foreign-policy professionals must have a clear-headed understanding of the nature of relationships in the international sphere. They must also be aware that the 'national interest', by which the game of international relations is often assumed to be guided, is a complex, contested and changing notion. They must remember that if Australia pursues its interests (however defined), then other countries must be allowed to pursue theirs as well. They must be aware that, just as in physics, every action on the part of one country will have a reaction on the part of others. This is most clearly seen with the discussion and implementation of 'defensive' schemes and weapons which, in certain circumstances, may lead to an escalation of tensions and an arms race. In a related 
sense, they must be aware that a fortress mentality generally does more harm than good.

The models we use to understand international relations have undergone the most extraordinary ferment over the past couple of decades. Models, including the 'realist' and the 'liberal' approaches, are certainly important. They provide the compass by which we navigate the seas of international relations. But, for any practitioner, they also present pitfalls and dangers. There is a danger that the model will substitute for the reality, or that the model will distort the appreciation of information. If the model becomes primary, and is not simply recognized as a tool, then (however good it might be) it increases the danger of conflict. Fashions in this area ought to be resisted, especially if they include suggestions of historical inevitability or necessity. Assumptions and models must always be tentative.

There are two issues, in particular, that test a professional approach to policymaking in our present circumstances. They concern the issues of 'friendship' in international relations, and 'national interests'. It is to them that I shall now turn.

\section{Friendship}

Australia's relationship with the United States is very important. It has significant historical depth; it is based on shared values; and it has a crucial military component. As a recent defence White Paper explained, Australia depends on US military technology to maintain its capacity for self-defence: 'The kind of ADF that we need is not achievable without the technology access provided by the US alliance' (Department of Defence 2000, 35). But Australia's role within the region may be hindered by its relationship with the United States; especially when Australia is seen by some regional states as the agent of the United States. Paul Hasluck, a foreign-policy professional who became Minister for External Affairs, reflected that his Prime Minister's 1966 slogan 'all the way with L.B.J.' was 'one of the most harmful slogans we had to counteract in our diplomacy when seeking to bring an understanding of Australia's interests and respect for our policies' into Asia (Hasluck 1997, 145). If it wishes to act as an honest broker in relations in the region, Australians must understand better the nature of true friendship.

The United States itself can show us the way on this issue. Its first President, George Washington, in his farewell address to the people of the United States in 1796, had some good advice for countries in our position. For, in some respects, the United States was then in the same position. Washington argued for an independent and honest course in foreign affairs, and explained: "nothing is more essential than that permanent, inveterate antipathies against particular nations and passionate attachments for others should be excluded; and that in place of them just and amicable feelings towards all should be cultivated. The nation which indulges towards another an habitual hatred or an habitual fondness is in some degree a slave. It is a slave to its animosity or to its affection, either of which is sufficient to lead it astray from its duty and its interest.' A government must reject 
either course. If the national propensity is towards ill will or resentment, the government might adopt what the best calculations of policy would reject. If the propensity is towards passionate attachment, there are other evils to face. As Washington said: 'Sympathy for the favorite nation, facilitating the illusion of an imaginary common interest where no real common interest exists, and infusing into one the enmities of the other, betrays the former into a participation in the quarrels and wars of the latter, without adequate inducement or justification.' A free people must deal honestly and justly with all nations, and avoid foreign influence.

Much has changed in international relations over the past 200 years, especially the rise of the United States from fledgling nation to world power. But much that is fundamental to the ways humans conduct their affairs has remained the same. Washington's address may be seen as underpinning the doctrine of isolationism, which seems to have a fluctuating influence upon US policy-makers, but his remarks on friends and enemies-about the approach to policy-making-are unequivocal.

Of course, friendship in the international sphere-between countries of different power-is a complicated matter. It must deal with the truth that the Athenians pointed out to the Melians before invading them, 2,500 years ago: 'right $\ldots$ is only in question between equals in power, while the strong do what they can and the weak suffer what they must' (Thucydides 1952, 505). Since the Treaty of Westphalia, the realities of power have been in constant tension with the formalities of equality.

Friendship in any sphere is not uncritical. Nor is it fawning, or flattering. Nor is it exclusive. Friends can, and do, disagree. Even their interests can diverge on one or more levels. If anything, friendship means an ability to be frank, and to be taken seriously when being frank. Real friendship sometimes requires courage. As Edmund Burke wrote in 1777 when he was being frank to his constituents (defending his opposition to laws passed by the English Parliament against the rebellious American colonists): 'I cannot purchase the favour of any man by concealing from him what I think his ruin' (Burke 1910, 37).

Australia's friendships are voluntarily entered into. But they sometimes bring with them the sense of being locked into a larger arrangement, reinforced by a type of blackmail (over the purchase of military materiel, and access to intelligence, for example). Australia must be able to differ with its friends. Perhaps then it will know who its friends really are.

\section{Interests}

It is a useful rule of thumb that nations follow their interests in foreign relations. But we should not allow that assumption to blind us to the fact that 'interests' can be a self-fulfilling hypothesis, and that interests can change by our own intervention. We should not rely on the notion of 'national interests' unthinkingly. 
The 'national interest' is not something fixed and given, but something that develops and evolves. Countries pursuing their national interest are also countries that are in the process of defining and redefining that interest. In this section, I want to examine the notion of interests and what it can tell us, and caution that we should not rely on interests as much as we do when we analyse international relations.

The notion that interests are a major motivation for humans, and give us an ability to make accurate predictions about their behaviour, is old. In fact, the incorporation of 'interests' into the language of politics, in the mid-seventeenth century, marked the beginning of modern politics. 'Interest' is one of the key factors in the claim to making the study of politics scientific; as opposed to the impulsiveness of 'passions', interest suggested calculation. 'Interest' quickly became the predominant way of thinking about human affairs, and seemed 'so self-evident a notion that nobody bothered to define it precisely' (Hirschman 1977, 43).

Though it now plays a major role in the analysis of politics more generally, the first systematic discussions of interest arose in relation to foreign affairs. In 1638, the Duke of Rohan first published his Treatise of the Interest of the Princes and States of Christendom which soon became a major influence on English political thought. Rohan advised princes to put aside irrational prejudices and the advice of unreliable councilors, and pursue their goals as defined by the objective requirements of national preservation and the European balance of power. Rohan stressed calculation, and came up with a quote for which he would become well known: 'l'interest seul ne peut jamais manquer' (cited Gunn 1968, 553) which was properly rendered as 'interest alone can never fail', but ultimately became 'interest will not lie'. This summed up something people were increasingly eager to embrace: the notion that knowing and pursuing your interests will not lead you astray. In 1658 this message was taken up by Marchamont Nedham in his treatise Interest Will Not Lie, who explained that 'interest' had two meanings. The first was that if men knew their interests correctly (a source of much later contention) they would not be deceived into pursuing the ends of other men; the second, important for our purposes, was that if you can apprehend wherein a man's interest to any particular game on foot doth consist, you may surely know, if the man be prudent, wherabout to have him, that is, how to judge of his design' (cited Gunn 1968, 557). This emphasis on rational calculation allowed 'interest' to be extended from foreign affairs to the realms of any prudent man.

Modern politics is thus the age of interest, when individuals, classes and nations follow their interests. Hans Morgenthau's realist conception of international relations, in contrast to the Wilsonian idealism that preceded it, was explicitly based on the notion of interest. Realism, he argued, finds 'its way through the landscape of international politics' by 'the concept of interest defined in terms of power... Without such a concept a theory of politics, international or domestic, would be altogether impossible...We assume that statesmen think and 
act in terms of interest defined as power, and the evidence of history bears that assumption out' (Morgenthau 1965, 5). Morgenthau may have been right to argue that we should not look solely to the publicly-declared motives of statesmen to understand foreign policies. But his shift of focus onto interest makes the study of international politics no more certain. Morgenthau argues that politics is about maximizing power, and he adds that the standards of politics are supreme above all others, including economic and moral standards (12).

Nevertheless, the notion of interest as power is too narrow to usefully comprehend the reality of interests. And it is notable that having made his definition of power at the outset, Morgenthau spends little time on its concrete content for the remaining 600 pages of his seminal book. Whatever other objectives states may have, he sees power as fundamental. But this must be regarded as an assumption, not as a fact. I am not suggesting that formulations of interest are not useful, especially in so far as they involve careful consideration and caution against impulsiveness. But the great difficulty is to give any coherent content to the notion of interest in any particular case.

This is the great difficulty with the notion of 'interest'. For it is often used in a circular fashion in political debate, and is argued ex post facto. That an action is done (a position taken, a goal defined, an alliance concluded, a campaign begun, and so forth) is used as evidence that an interest existed which resulted in that action. But we need to be cautious, especially as so many people use the term 'interest' as an explanation for many or even most behaviours when they are merely describing them in a different way. The identification of interest can also be self-fulfilling; merely positing an interest can sometimes result in it being pursued and fulfilled. 'Interest' has become unassailable in another sense also: if someone does not follow what others see as his/her 'interest', he or she is declared not to have perceived or understood her interest. In other words, the distinction between having an interest and perceiving it, the objective and subjective dimensions of interest, are used in such a way that the content of interest can never be controverted. If people have not followed their interest, then they haven't properly understood them.

The content of interests is difficult to determine with any precision. Historical attempts to pin-point and measure interests have failed, for the very reason that they are not fixed. Let us accept that for general purposes, interests are aspirations that people think are realizable. We can certainly make some reasonable judgements about the national interests of countries, incorporating knowledge of their objective situation, their history and their stated aspirations. But not only is it difficult to determine precisely what national interests are at any particular moment, they change over time. As John Plamenatz explained, with characteristic clarity but also with characteristic 1950 s sexism, 'A man's pursuit of his interest is not a chase that does not change the nature of the quarry. It is as a competitor, a collaborator, and a negotiator with other men that a man acquires the ambitions and settled preferences he calls his interests; and the same is true of classes of 
men. The pursuit of interest, unlike the hunt, is like war or marriage, where conflict and collaboration quite change the nature of the objects for whose sake they were first undertaken' (Plamenatz 1954, 7). The same may be said of the interests of nations.

\section{Conclusion}

I wrote at the outset about a broad and fundamental transition in international relations. But it is the relationship between the United States and China that will set the strategic scene for the coming decade and well beyond. Whether that relationship is primarily adversarial or cooperative is something that is important to Australia, and something that Australia can help to influence. Australia is constrained in what it can do in the region, and in this larger strategic relationship. It is a middle-level power. Our military means are not enough to mount more than minor operations of our own, or to support allied forces. And yet, on the diplomatic front we have played, and can continue to play, a substantial role by virtue of intelligence, perspective and tact. The Chinese and the Americans must themselves play the decisive part in their own relationship, but it is inevitable that Australia will be involved, and we must be ready with a considered, long-term view. The coming decade will test the mettle of our foreign-policy professionals.

In many respects, Australia has a good international, and a growing regional, reputation. Its history as an outpost of British imperialism, and its own struggles to better fix its identity and confront domestic problems, may be an easy target for cynical politicians overseas for their own domestic political consumption. There is nothing we can do to alter Australia's past, but we should not be ashamed at some of its major legacies: parliamentary government under the rule of law, the prosperity that comes from a market economy, and a tolerance of diversity. Our people and our achievements must speak for themselves, because-beyond a minimal level-our government cannot speak for them. One of the things that holds us back in developing real attitudes of self-reliance, and confronting the region unashamedly, is an exaggerated sense of the burdens of our history and the problems with our culture. Australia lacks a sense of self-confidence, and looks elsewhere for a sense of affirmation; it is uneasy about its sense of identity. We must understand our strengths as strengths, and not apologize for them. We must confront our weaknesses, and deal with them on our own terms. Such a change of attitude cannot be conjured up. It cannot be manufactured by public-relations campaigns by government departments or bombastic politicians. This is a more fundamental problem in our approach, but it should at least be noted.

The role of foreign-policy professionals is a vital, and distinguished, one. Apart from conveying their expertise to government, their role is sometimes to advise restraint upon their political masters, and to think of the longer term. The pressures on policy professionals are different from those upon politicians, who must seek re-election, and must consequently keep touch with the people. Bowing to the people's prejudices, instead of informing and educating them-leading them-is 
one of the greatest temptations of the democratic politician. Genuine political leadership in a democracy is the ability to enlighten the reason of the people, not to flatter their passions or pander to their prejudices.

To engage with the region, to give ourselves the best chance of benefiting by its development and contributing to its security, Australia must be prepared to face the challenges as they arise without being constrained by an exaggerated and uncritical sense of friendship with the United States, but with a sense of our intrinsic connection to the region, and with a confidence that we have a legitimate role to play. In all of this, the guidance of the foreign-policy professional will be crucial.

\section{References}

Burke, Ednund. 1910. The Works of Edmund Burke. Vol. 2. London: George Bell and Sons.

Department of Defence. 2000. Defence 2000: Our Future Defence Force. Canberra: Commonwealth of Australia.

Gunn, J.A.W. 1968, "Interest Will Not Lie": A Seventeenth-Century Political Maxim". Journal of the History of Ideas. 29:4, pp. 551-64.

Hamilton, Keith and Richard Langhome. 1995. The Practice of Diplomacy: Its Evolution, Theory and Administration. London: Routledge.

Hasluck, Paul. 1997. The Chance of Politics. Melbourne: Text.

Hirschman, Albert O. 1977. The Passions and the Interests: Political Arguments for Capitalism Before its Triumph. Princeton NJ: Princeton University Press.

Kelly, David and Anthony Reid. 1998. Asian Freedoms: The Idea of Freedom in East and Southeast Asia. Cambridge: Cambridge University Press.

Kissinger, Henry. 1994. Diplomacy. New York: Simon and Schuster.

Morgenthau, Hans J. 1965. Politics Among Nations: The Struggle for Power and Peace. 3rd ed. New York: Knopf.

Plamenatz, John. 1954. 'Interests'. Political Studies. 2:1, pp. 1-8.

Thucydides. 1952. The History of the Peloponnesian War. Chicago: Encyclopaedia Britannica. 